\title{
WATER AERATION RESEARCHES
}

\author{
Nicoleta Albu ${ }^{1}$, Nicolae Băran ${ }^{1}$, Octavian Donțu ${ }^{1}$, Ammar Almaslamani ${ }^{1}$, Mihaela Constantin ${ }^{1}$ \\ ${ }^{1}$ University Politehnica of Bucharest \\ Splaiul Independentei no. 313, sector 6, Bucharest \\ E-mail: nicoleta681105@yahoo.com, n_baranfimm@yahoo.com, \\ octavdontu@yahoo.com, ammar.fadhil88@yahoo.com, i.mihaelaconstantin@gmail.com
}

\begin{abstract}
The paper examines the possibility of increasing the dissolved oxygen content in the water by introducing compressed air into the waste water transport pipeline. A computation program is developed for the numerical integration of the equation of the oxygen transfer rate to water and the distance at which the saturated concentration of dissolved oxygen in water is reached is determined
\end{abstract}

Keywords: Water Aeration, Oxygen Dissolved in Water, Waste Water.

\section{Introduction}

By the aeration of water is meant the transfer of oxygen from the atmospheric air into the water, which is, in fact, a phenomenon of transfer of a gas into a liquid [1][2].

The most common method of removing organic impurities under the action of aerobic biomass is the introduction of oxygen gas into the wastewater.

Oxygen comes most commonly from atmospheric air, in this case the process bearing the name of water aeration (fig. 1).

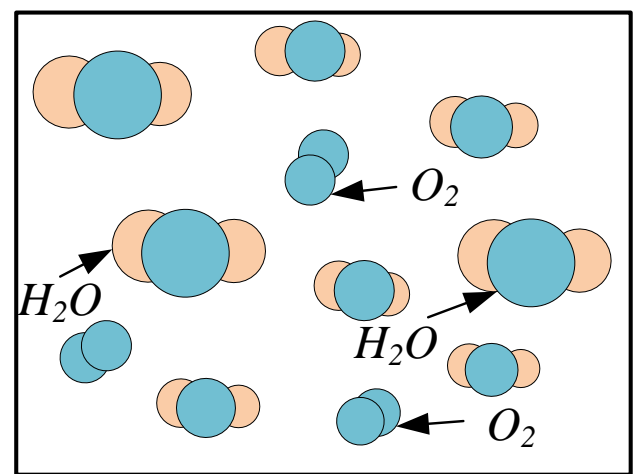

Figure 1: View of the molecular structure: dissolved oxygen [3].

From the above figure one can seen that each water molecule consists of an oxygen molecule connected to two hydrogen molecules (the blue sphere coupled to two pink spheres). The oxygen molecules (blue spheres) that constitute dissolved oxygen can be found among water molecules. The maximum amount of oxygen that can be dissolved in water depends on a number of physical and chemical parameters, such as: atmospheric pressure, water temperature, water salinity, degree of water turbulence [4][5][6].

Water temperature is an important factor, so the warmer the water, the lower the dissolved oxygen concentration. Therefore [7][8]:

- at $\mathrm{t}=10^{\circ} \mathrm{C}$, in fresh, clean water, an amount of $11.3 \mathrm{mgO}_{2} / \mathrm{dm}^{3}$ can be absorbed;

- at $\mathrm{t}=25^{\circ} \mathrm{C}$, in clean water, only $8.3 \mathrm{mgO}_{2} / \mathrm{dm}^{3}$ can be absorbed.

Water aeration leads to an increase in the dissolved oxygen concentration in the water.

Aeration is necessary to improve water quality, to avoid the occurrence of oxygen deficiency in systems where there is biochemical oxygen consumption above the water self-aeration capacity, to eliminate the toxic gases that can be found in water and in the process of wastewater purification [9] [10].

The main purpose of water aeration, regardless of the industry and the reason for its use, is to increase or maintain an optimal level of dissolved oxygen in a mass of water.

The oxygen needed for the aeration process is taken from the atmospheric air and introduced into the water. In order for this aeration to be effective, a uniform dispersion of air must be ensured throughout the water body in a tank or basin; the air must be spread evenly to provide oxygen.

A distinction must be made between the term "aeration" and "oxygenation" of the wings:

- Water aeration refers to the introduction of atmospheric air into the water;

- Water oxygenation refers to the introduction of a gas mixture: [10];

$>$ atmospheric air + oxygen from a cylinder

$>$ low nitrogen air delivered by oxygen concentrators [10] [11]. 


\section{Analysis of Two-phase Fluid Flow Through a Horizontal Pipe}

An air bubble emitted in the water has a certain space available to rise vertically [12]. This space is the inside diameter of the pipe (figure 2).

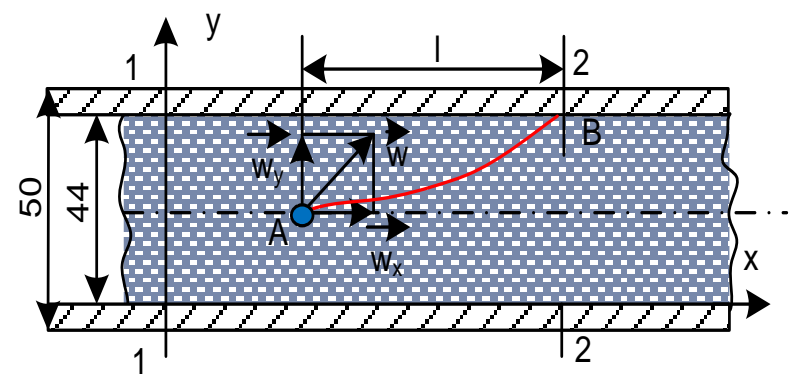

Figure 2: The trajectory of an air bubble in the case of water flow through horizontal pipes

During the flow the air bubble speed has two components:

$\mathrm{W}_{\mathrm{x}}$ - speed on the ox axis;

$\mathrm{w}_{\mathrm{y}}$ - speed on the oy axis

Due to the water and air speed, the air bubble will travel a curvilinear trajectory.

The problem formulation.

1) At what distance (1) (figure 2) will the air bubble come out of the water?

2) At the distance "l" was the concentration of dissolved oxygen reached in water from $\mathrm{C}_{0}$ to $\mathrm{C}_{s}$ ? (see section 1-1 and 2-2 performed on the horizontal pipe).

\section{Numerical Integration of the Oxygen Speed Transfer Equation to Water}

The equation of the rate of oxygen transfer in water is:

$$
\frac{\mathrm{d} C}{\mathrm{~d} \tau}=a \cdot k_{L}\left(C_{s}-C\right)
$$

where:

- C - concentration of dissolved oxygen at time $\tau$;

- $\mathrm{ak}_{\mathrm{L}}$ - the volumetric mass transfer coefficient;

- $\mathrm{C}_{s}$ - oxygen concentration in water, at saturation.

The values of $\mathrm{ak}_{\mathrm{L}}$ and $\mathrm{C}_{\mathrm{s}}$ are constant in time.

If the boundary conditions $\mathrm{C}=\mathrm{C}_{0}$ for $\tau=0$ are imposed, equation (1) can be integrated [14][15]:

$$
\frac{\mathrm{d} C}{C_{s}-C}=a \cdot k_{L} \mathrm{~d} \tau
$$

In the case of $\mathrm{C}<\mathrm{Cs}$, after integration, results:

$$
-\ln \left(C_{s}-C\right)=a \cdot k_{L} \cdot \tau+c t
$$

Constanta is obtained from the boundary condition:

$$
C=C_{0} \quad \text { for } \tau=0
$$

and it has the value

$$
c t=-\ln \left(C_{s}-C_{0}\right)
$$

Introducing (5) into (3):

$$
\begin{aligned}
& -\ln \left(C_{s}-C\right)=a \cdot k_{L} \cdot \tau-\ln \left(C_{s}-C_{0}\right) \\
& \ln \left(C_{s}-C\right)=\ln \left(C_{s}-C_{0}\right)-a \cdot k_{L} \cdot \tau \\
& \ln \left(C_{s}-C\right)=\ln \left(C_{s}-C_{0}\right)+\ln e^{-a \cdot k_{L} \cdot \tau} \\
& \ln \left(C_{s}-C\right)=\ln \left(\left(C_{s}-C_{0}\right) \cdot e^{-a \cdot k_{L} \cdot \tau}\right) \\
& C_{s}-C=\left(C_{s}-C_{0}\right) \cdot e^{-a \cdot k_{L} \cdot \tau} \\
& C=C_{s}-\left(C_{s}-C_{0}\right) \cdot e^{-a \cdot k_{L} \cdot \tau}
\end{aligned}
$$

initially $\tau=0$, so $C=C_{0}$

The equation is repeated in the form [16] [17]:

$$
C_{i+1}=C_{s}-\left(C_{s}-C_{i}\right) \cdot e^{-a \cdot k_{L} \cdot \tau_{i}}
$$

$$
\frac{C_{i+1}-C_{s}}{C_{s}-C_{i}}=-\frac{1}{e^{a \cdot k_{L} \cdot \tau_{i}}}
$$

It is considered that the two-phase mixture (water-air) moves along the ox axis with $\mathrm{w}=\mathrm{ct}$, so:

$$
\begin{aligned}
& \tau_{i}=\frac{\Delta x_{i}}{w} \\
& \frac{C_{s}-C_{i+1}}{C_{s}-C_{i}}=\frac{1}{e^{a \cdot k_{L} \cdot \frac{\Delta x_{i}}{w}}} \\
& e^{a \cdot k_{L} \cdot \frac{\Delta x_{i}}{w}}=\frac{C_{s}-C_{i}}{C_{s}-C_{i+1}}
\end{aligned}
$$

From previous research [9], $\mathrm{ak}_{\mathrm{L}}=0.042 \mathrm{~s}^{-1}$ and one can obtain:

$$
\begin{aligned}
& \frac{a \cdot k_{L}}{w}=\frac{0.042}{0.0115}=0.35 \\
& e^{0.35 \Delta x_{i}}=\frac{C_{s}-C_{i}}{C_{s}-C_{i+1}} \\
& \ln e^{0.35 \Delta x_{i}}=\ln \frac{C_{s}-C_{i}}{C_{s}-C_{i+1}} \\
& \Delta x_{i}=\frac{\ln \frac{C_{s}-C_{i}}{C_{s}-C_{i+1}}}{0.35}
\end{aligned}
$$

The relation (18) will be used in the calculation program in paragraph 4 . 


\section{Elaboration of a Calculation Program to Determine the Modification of the Dissolved Oxygen Concentration in Water According to the Distance Completed by the Two-Phase Mixture}

The logical scheme of the program has the following steps [18] [19] [20]:

1) The entry data is specified:

For water at $\mathrm{t}=24{ }^{\circ} \mathrm{C}$ from [9] one can obtain:

- initial value of dissolved oxygen concentration in water: $\mathrm{C}_{0}=5.84 \mathrm{mg} / \mathrm{dm}^{3}=0.00584$ $\mathrm{kg} / \mathrm{m}^{3}$

- value of dissolved oxygen concentration in water, at saturation: $\mathrm{Cs}=8.4 \mathrm{mg} / \mathrm{dm}^{3}=0.0084 \mathrm{~kg} / \mathrm{m}^{3}$

- water speed: $\mathrm{w}=0.0115 \mathrm{~m} / \mathrm{s}$

- the ratio $\mathrm{ak}_{\mathrm{L}} / \mathrm{w}=0.35$ (see relation 15)

2) It is successively calculated:

$$
\Delta x_{i}=\frac{\ln \frac{C_{s}-C_{i}}{C_{s}-C_{i+1}}}{0.35}
$$

3) Determine $\Delta x_{i}$ after "n" intervals (distances) at which the concentration $\mathrm{C}_{\mathrm{i}+1}$ reaches the threshold of dissolved oxygen concentration in water, at saturation, i.e. Cs.

4) At this moment, there is the distance completed by the two-phase mixture such that $\mathrm{C}_{0} \rightarrow \mathrm{C}_{\mathrm{s}}$; this distance specifies the length of the pipe at which $\mathrm{C}_{0} \rightarrow \mathrm{C}_{s}$ is obtained.

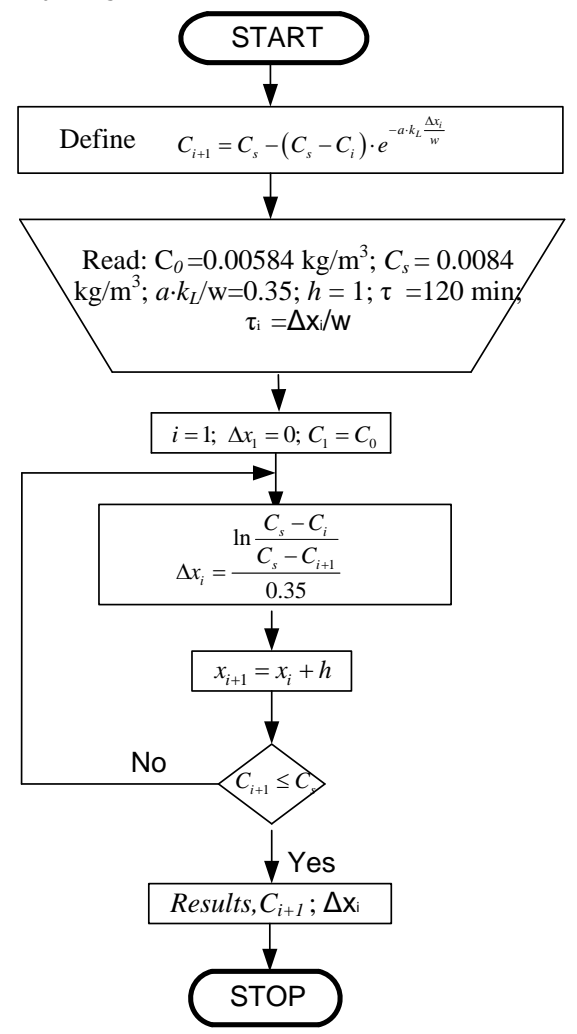

Figure 3: Logical calculation scheme of the program for calculating the variation of the dissolved oxygen concentration in the water according to the length of the distance until $C_{i+1}=C_{s}$
Table 1. Calculation results

\begin{tabular}{|c|c|c|c|}
\hline i & $\mathbf{C}_{\mathbf{i}}$ & $C_{i+1}$ & $\Delta \mathbf{x}_{\mathbf{i}}$ \\
\hline 1 & 0,00584 & 0,00594 & 0,113845 \\
\hline 2 & 0,00594 & 0,00604 & 0,118571 \\
\hline 3 & 0,00604 & 0,00614 & 0,123705 \\
\hline 4 & 0,00614 & 0,00624 & 0,129305 \\
\hline 5 & 0,00624 & 0,00634 & 0,135435 \\
\hline 6 & 0,00634 & 0,00644 & 0,142176 \\
\hline 7 & 0,00644 & 0,00654 & 0,149623 \\
\hline 8 & 0,00654 & 0,00664 & 0,157893 \\
\hline 9 & 0,00664 & 0,00674 & 0,167132 \\
\hline 10 & 0,00674 & 0,00684 & 0,177519 \\
\hline 11 & 0,00684 & 0,00694 & 0,189284 \\
\hline 12 & 0,00694 & 0,00704 & 0,202719 \\
\hline 13 & 0,00704 & 0,00714 & 0,218209 \\
\hline 14 & 0,00714 & 0,00724 & 0,236262 \\
\hline 15 & 0,00724 & 0,00734 & 0,257575 \\
\hline 16 & 0,00734 & 0,00744 & 0,283117 \\
\hline 17 & 0,00744 & 0,00754 & 0,314288 \\
\hline 18 & 0,00754 & 0,00764 & 0,353183 \\
\hline 19 & 0,00764 & 0,00774 & 0,403082 \\
\hline 20 & 0,00774 & 0,00784 & 0,469437 \\
\hline 21 & 0,00784 & 0,00794 & 0,562029 \\
\hline 22 & 0,00794 & 0,00804 & 0,70035 \\
\hline 23 & 0,00804 & 0,00814 & 0,929778 \\
\hline 24 & 0,00814 & 0,00824 & 1,387165 \\
\hline 25 & 0,00824 & 0,00834 & 2,802369 \\
\hline
\end{tabular}

Based on the data in table 1, the graph in figure 4 was drawn.

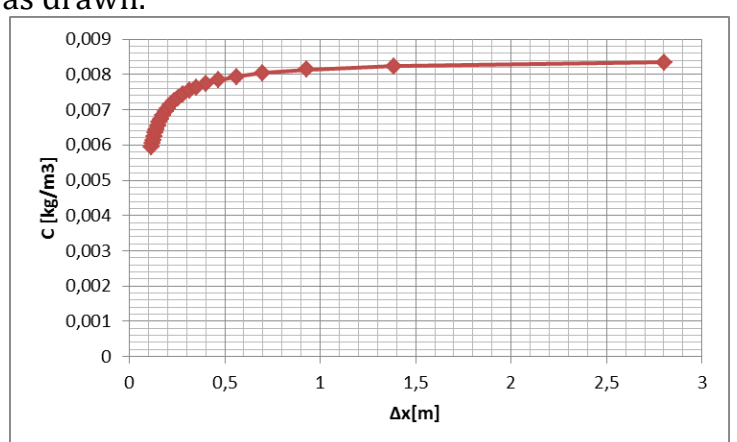

Figure 4: Graphical representation of the function

$$
\mathrm{C}_{02}=f(x)
$$

From figure 5 one can observe that the value of the dissolved oxygen concentration in water rapidly increases over a distance (pipe length) of $1 \mathrm{~m}$, and subsequently reach the value of the saturation concentration $\left(\mathrm{C}_{\mathrm{s}}\right)$ over a distance of about $2 \mathrm{~m}$. The allure of the curve $\mathrm{C}_{02}=\mathrm{f}(\mathrm{x})$ and the obtained values are similar to the data from other specialized papers [18][19][20]. The theoretical results obtained above will be validated by experimental researches that will be carried out in the immediately following 
period in the laboratories of the University Politechnica of Bucharest.

\section{Conclusions}

The paper aims to implement a reliable and economical solution for water aeration.

The proposed solution, i.e. aeration of fluids flowing through pipes is more advantageous compared to the existing procedures in practice because:

- eliminates those large aeration basins from the water treatment plants, thus reducing the investment cost.

- the electricity consumption for the water aeration is reduced.

- the operating and maintenance costs of the water treatment station are reduced..

- the quality control of the fluid subjected to the aeration process is easy to perform with the help of digital oxygenometer that use a non-invasive measurement method.

\section{Acknowledgements}

This work was supported by a grant of the Romanian National Authority for Scientific Research and Inovation, CCDI - UEFISCDI, project number Manunet - MINET 17/ENER 2307-CEBIOTREAT within PNCDI III.

\section{References}

[1] G. Oprina, I. Pincovschi, G. Băran, Hidro-GazoDinamica Sistemelor de aerare echipate cu generatoare de bule, Ed. POLITEHNICA PRES, Bucureşti, 2009.

[2] H. Chansonn, Air-Water Interface Area in SelfAerated Flows, Water Res, IA WPRC, vol. 28, no.4, pp. 923-929 (ISSN 0043-1354).

[3] Al. S. Pătulea, Influenţa parametrilor funcţionali şi a arhitecturii generatoarelor de bule fine asupra eficienţei instalaţiilor de aerare, Teză de doctorat, Universitatea Politehnica din București, 2012.

[4] G. Oprina, Contribuţii la hidro-gazo-dinamica difuzoarelor poroase, Teză de doctorat, Universitatea Politehnica din Bucureşti, Facultatea de Energetică, 2007.

[5] G. M. Mateescu, Hidro-gazo-dinamica generatoarelor de bule fine, Teză de doctorat, Universitatea POLITEHNICA din București, Facultatea de Mecanică şi Mecatronică, București, 2011.

[6] C.N.S. Law, B.C. Khoo, Transport across a turbulent air-water interface. AICHE Journal, 48(9), 1856-1868 [doi: 10.1002/aic.690480904], 2002.

[7] M. Vlăsceanu (Banu), D. Robescu, M. Căluşaru (Constantin), Theoretical and experimental research concerning the modification of dissolved oxygen concentration in aeration tanks equipped with surface aerators, Buletinul Științific al Universității Politehnica din București, seria D, Inginerie Mecanică, Editura Politehnica Press, vol.77, nr. 1, pp. 177-184, 2015.

[8] M. Constantin, N. Băran, B. Tănase, R. Mlisan (Cusma), Research regarding the free surface water aeration, TERMOTEHNICA, nr. 2, pp. 8286, 2014.

[9] R. Mlisan (Cusma), Influenţa arhitecturii generatoarelor de bule fine asupra concentraţiei de oxigen dizolvat în apă, Teză de doctorat, Universitatea Politehnica din București, 2017.

[10] B. Tănase, Influența compoziției gazului insuflat în apă asupra conținutului de oxigen dizolvat, Teză de doctorat, Universitatea Politehnica din București, 2017.

[11] R. D. Păun, Cercetări privind utilizarea concentratoarelor de oxigen la oxigenarea apelor, Teză de doctorat, Universitatea Politehnica din București, 2019.

[12] E. C. Gh. Isbăşoiu, Tratat de mecanica fluidelor, Editura Agir, Bucureşti, 2011.

[13] N. Băran, I. M. Căluşaru, G. Mateescu, Influence of the architecture of fine bubble generators on the variation of the concentration of oxygen dissolved in water, Buletinul Stiintific al Universitatii POLITEHNICA din Bucuresti, Ed. Politehnica Press, seria D, Inginerie Mecanică, vol.75, nr. 3/2013, pp. 225-236.

[14] H.M. Antia, Numerical Methods for Scientists and Engineers, Birkhauser Publishing Limited Basel, Switzerland, ISBN 3-7643-6715-6, 2002.

[15] G. C. Everstine, Numerical Solution of Partial Differential Equations, Gaithersburg, Maryland, 2010.

[16] D. Houcque, R. McCormick, Applications of MATLAB: Ordinary Differential Equations (ODE), School of Engineering and Applied Science - Northwestern University, Ilinois, 2007.

[17] Won-Yong Yang, J. Morris, Applied Numerical Methods Using Matlab, Wiley-Interscience, John Wiley \& Sons. INC, 2005.

[18] M. Căluşaru-Constantin, B. Tănase, N. Băran and R. Mlisan-Cusma, „Researches Regarding the Modification of Dissolved Oxygen Concentration in Water", IJISET - International Journal of Innovative Science, Engineering \& Technology, Vol. 1 Issue 6, 2014, pp. 228-231.

[19] A. Pătulea, N. Băran, I. Căluşaru, Measurements of Dissolved Oxygen Concentration in Stationary Water, World Environment (Scientific \& Academic Publishing), Rosemead, CA, 91731, USA, vol. 2(5), pp. 104-109, 2012.

[20] E.L. Schierholz, S.C. Wilhem, H.E. Henneman, Gas transfer from air diffusers, Water Research, vol. 40, p.1018-1026, 2006 